Studia z Dziejów Średniowiecza, t. 23, 2019

\author{
Sławomir Jóźwiak \\ (Instytut Historii i Archiwistyki \\ Uniwersytet Mikołaja Kopernika w Toruniu) \\ Janusz Trupinda \\ (Muzeum Zamkowe w Malborku)
}

\title{
Czas powstania krzyżackiego komturstwa w Pokarminie (Brandenburg) a kwestia chronologii wznoszenia tamtejszego zamku
}

https://doi.org/10.26881/sds.2019.23.04

Keywords: castles, castle in Pokarmin (Barndenburg), Prussia, Teutonic Order

Krzyżacki kronikarz, piszący swoje dzieło w latach dwudziestych XIV w. (do 1330 r.), Piotr z Dusburga, pod rokiem 1266 zamieścił informację, iż wówczas na czele znacznego pocztu zbrojnych przebywał w Prusach margrabia brandenburski Otton III. Co prawda militarnie nie udało mu się tam zdziałać niczego nadzwyczajnego, ale za radac władz zakonnych wybudował warownię (,castrum”), która od nazwy marchii, którą władał, otrzymała miano Brandenburg (pol. Pokarmin, ros. Uszakowo, $19 \mathrm{~km}$ na południowy zachód od Królewca) ${ }^{1}$. Jak nieco dalej informował kronikarz, jeszcze zapewne w tym samym lub w następnym roku (1267), kiedy Fryderyk von Holdenstedt, komtur Pokarmina, wraz ze swoimi zbrojnymi prowadził aktywną akcję militarną w okolicach Krzyżporka (niem. Kreuzburg, ros. Sławskoje,

1 „Anno Domini 1266 marchio Brandenburgensis, ut praemissum est, cum multitudine pugnatorum venit ad terram Prussiae, et cum aliud agere non posset, de consilio magistri et fratrum aedificavit castrum Brandenburgk, quod a nomine marchionatus sui ad perpetuam memoriam sic voluit appellari” - Petrus de Dusburg, Chronica terrae Prussiae (dalej: Dusburg), wyd. J. Wenta, S. Wyszomirski [w:] MPH, s.n., t. 13, Cracoviae 2007, s. 135. 
$20 \mathrm{~km}$ na południe od Królewca), jego warownia została zdobyta i spalona przez Warmów, ale udało się uratować braci zakonnych wraz z ich pachołkami, którzy bronili się w tamtejszej drewnianej wieży (co byłoby ważna przesłanką do stwierdzenia, że forteca ta nie była jeszcze wówczas wzniesiona ani z kamienia, ani z cegły) ${ }^{2}$. Najpewniej przed połową $1267 \mathrm{r}$. margrabia Otton na czele zbrojnej wyprawy ponownie pojawił się w Prusach i nakazał odbudować warownię w Pokarminie w tym samym co poprzednio miejscu ${ }^{3}$.

Zawarta $\mathrm{w}$ drugim $\mathrm{z}$ przytoczonych fragmentów podana przez Piotra z Dusburga informacja o aktywnie działajacym na tym obszarze w 1266/1267 r. komturze pokarmińskim, Fryderyku von Holdenstedt, doprowadziła do dość poważnego zamieszania w dotychczasowej historiografii. Oto bowiem jeszcze w pierwszej połowie XIX w. Johannes Voigt przyją, że tamtejsze komturstwo zostało przez władze zakonne wykreowane w 1266 r. ${ }^{4}$ Odtąd znaczna część późniejszych badaczy bezkrytycznie powielała propozycję królewieckiego archiwisty ${ }^{5}$. Pewne wątpliwości wyrażali jedynie Dieter Wojtecki i Maciej Dorna. Pierwszy z nich zauważył, że wspomniany Fryderyk von Holdenstedt dowodnie między 14 lutego 1266 a 22 lutego1270 r. był w Prusach

2 „Frater Fridericus de Holdenstete commendator de Brandenburgk cum fratribus et armigeris suis profectus fuit ad territorium Nattangiae, quod dicitur Solidow circa castrum Cruceburgk, et per incendium et rapinam occisis et captis plurimis devastavit. In reditu occurrit ei nuntius, qui dixit, quod castrum Brandenburgk esset destructum [...]. Quo audito commendator turbatus ivit cum suis versus Könnigsbergk et reversus navigio Brandenburgk fratres et aliquos de familia sua, qui se in turri lignea dicti castri defenderant, ab impetu et impugnatione Pruthenorum salvos secum dunit" - ibidem, s. 136.

3 „Marchio de Brandenburgk intelligens, quod castrum per eum aedificatum esset a Pruthenis destructum, turbatus est et collecto iterum magno exercitu rediit Prussiam et de magistri et fratrum consilio ad eundem locum castrum aliud eiusdem nominis instauravit" - ibidem, s. 136-137. Ta wyprawa musiała się odbyć najpóźniej w pierwszej połowie 1267 r., gdyż margrabia Otton zmarł $9 \mathrm{X}$ tego roku - por. E.J. Guttzeit, Die Ordensburg Brandenburg am Frischen Haff [w:] idem, Natangen, Landschaft und Geschichte. Gesammelte Beiträge, hrsg. v. U. Arnold, K. Forstreuter, Marburg/ Lahn 1977, s. 110.

4 J. Voigt, Namen-Codex der Deutschen Ordens-Beamten, Königsberg 1843, s. 22.

5 W ten sposób: R. Wenskus, Das Ordensland Preußen als Territorialstaat des 14. Jahrhunderts [w:] Der deutsche Territorialstaat im 14. Jahrhundert, hrsg. v. H. Patze, „Vorträge und Forschungen” 1970, Bd. 13, s. 359; K. Militzer, Von Akkon zur Marienburg. Verfassung, Verwaltung und Sozialstruktur des Deutschen Ordens 1190-1309, Marburg 1999 (,Quellen und Studien zur Geschichte des Deutschen Ordens", Bd. 56), s. 351. 
marszałkiem ${ }^{6}$, a trudno byłoby zakładać, że pełnił on wspomniane dwie funkcje jednocześnie. Być może więc wydarzenia opisane przez Dusburga należałoby - zdaniem Wojteckiego - odnieść do okresu późniejszego ${ }^{7}$. Ale do jakiego? Z kolei Dorna przyjał, że Fryderyk von Holdenstedt był marszałkiem w Prusach między 1264 a 1270 r., a z całą pewnością również w roku 1266 r., kiedy to Dusburg widział go jako komtura pokarmińskiego ${ }^{8}$. Jednak w kontekście prowadzonych tu analiz warto zasygnalizować, że to zapewne właśnie Fryderyk von Holdenstedt przynajmniej od marca 1276 do końca tego samego roku pełnił urząd komtura Natangii ${ }^{9}$. Maciej Dorna podją także próbę odpowiedzi na pytanie, kiedy Fryderyk von Holdenstedt mógł być komturem pokarmińskim, ale jego propozycja, iż sprawował tę funkcję przed 1266 r. lub też między 1270 a 1276 r. ${ }^{10}$ jest nie do przyjęcia, gdyż w tym czasie urząd ten po prostu jeszcze nie istniał ${ }^{11}$, a po raz ostatni w zachowanych źródłach Fryderyk von Holdenstedt pojawił się w dokumencie z sierpnia $1279 \mathrm{r}$. jako zwierzchnik konwentu elbląskiego ${ }^{12}$. Pomyłkę kronikarza można więc chyba wyjaśnić jedynie w ten sposób, że dla Dusburga urząd komtura Natangii, który Holdenstedt sprawował w 1276 r., byłby tożsamy z wykreowana później funkcją komtura pokarmińskiego, co - jak będzie o tym mowa dalej - wydaje się całkiem prawdopodobne.

6 Codex diplomaticus Warmiensis oder Regesten und Urkunden zur Geschichte Ermlands (dalej: CDW), hrsg. v. C.P. Woelky, J.M. Saage, Bd. 1, Mainz 1860, nr 49; Urkundenbuch des Bisthums Samland (dalej: UBS), hrsg. v. C.P. Woelky, H. Mendthal, Bd. 1, Leipzig 1891, nr 95; Urkundenbuch des Bisthums Culm, Bd. 1, T. 1-2, hrsg. v. C.P. Woelky, Danzig 1885-1887, nr. 80.

7 D. Wojtecki, Studien zur Personengeschichte des Deutschen Ordens im 13. Jahrhundert, Wiesbaden 1971, s. 162. Badacz ten jako pierwszy wyraził przypuszczenie, że wymieniony w liście świadków dokumentu z 29 III 1276 r. „frater Fridericus commendator Nathangie" (P, nr 278) mógł być tożsamy z Fryderykiem von Holdenstedt. $\mathrm{Na}$ ten temat zob. dalej.

8 M. Dorna, Bracia zakonu krzyżackiego $w$ Prusach $w$ latach 1228-1309. Studium prozopograficzne, Poznań 2004, s. 156-157; idem, Die Brüder des Deutschen Ordens in Preußen 1228-1309. Eine prosopographische Studie, Wien-Köln-Weimar 2012 , s. $168-169$.

9 Zob. dalej. M. Dorna błędnie podał, że Fryderyk był komturem Natangii do końca 1277 r. - zob. M. Dorna, Bracia..., s. 156, idem, Die Brüder..., s. 168. Tymczasem w liście świadków dokumentu wystawionego 1 I 1277 r. był już wzmiankowany „frater Cvno commendator Nathangie” - UBS, nr 107.

10 M. Dorna, Bracia..., s. 157; idem, Die Brüder..., s. 168-169.

11 Na ten temat zob. dalej.

12 M. Dorna, Bracia..., s. 157; idem, Die Brüder..., s. 168. 
Nie ma w każdym razie żadnych wątpliwości co do tego, że zdecydowanie najstarszym krzyżackim ośrodkiem administracji terytorialnej na omawianym tu obszarze było komturstwo bałgijskie. Zwierzchnik tego konwentu wymieniony został w liście świadków odnowionego przywileju chełmińskiego z 1 października 1251 r. ${ }^{13}$ Trudno wątpić również $\mathrm{w}$ to, że komturstwo pokarmińskie wydzielono w późniejszym czasie z terytorium wcześniej podległego władzy krzyżackich administratorów rezydujacych w Bałdze. Kiedy jednak do tego doszło?

Co prawda kwestię tę próbowano już wyjaśnić w dotychczasowej literaturze przedmiotu ${ }^{14}$, jednak konieczność uwzględnienia szerszej bazy źródłowej oraz zweryfikowania i uściślenia znanych przekazów każe ponownie pochylić się nad tym zagadnieniem.

Poza wyżej wspomnianą wzmianką u Dusburga nie ma żadnych innych informacji źródłowych, które dowodziłyby, że wykreowanie komturstwa pokarmińskiego miało miejsce w latach sześćdziesiątych XIII w. A co można na ten temat powiedzieć na podstawie przekazów pisanych, zredagowanych w kolejnej dekadzie tego stulecia? Zainteresowanie wzbudzają wzmiankowani w tym czasie krzyżaccy urzędnicy z terytorium Natangii. Oto bowiem po stłumieniu wielkiego powstania pruskiego władze krzyżackie, najprawdopodobniej w 1274 r., utworzyły dla części tego obszaru nowy ośrodek komturski z siedziba w Kreuzburgu/Krzyżporku ${ }^{15}$. Już jednak od stycznia do marca 1276 r. obok komtura bałgijskiego pojawiał się w źródłach wójt natangijski ${ }^{16}$. $\mathrm{Z}$ kolei począwszy od 29 marca 1276 do 7 stycznia 1278 r. urzędnik ten był wymieniany z tytułem komturskim, zawsze jednak w listach świadków dokumentów wówczas wystawianych występował obok administratora bałgijskiego ${ }^{17}$. Autor Inflanckiej Kroniki Rymowanej, omawiając wielką krzyżacką kapitułę generalna z wczesnej jesieni

13 „Frater [...] Mengotus in Balga [...] commendator” - K. Zielińska-Melkowska, Przywilej chetmiński 1233 i 1251, red. Z. Zdrójkowski, przeł. W. Wróblewski, Toruń 1986, s. 49.

14 Por. S. Jóźwiak, Centralne i terytorialne organy władzy zakonu krzyżackiego $w$ Prusach w latach 1228-1410. Rozwój-Przeksztatcenia-Kompetencje, Toruń 2001, s. $61-64$.

15 W liście świadków dokumentu z 5 IX 1274 r. pojawił się „frater Rudewicus commendator in Cruceburch" - AP w Toruniu, Kat. I: Listy i dokumenty, nr 10; PrUB, Bd. 1/2, nr 323. Jest to jedyna wzmianka o tym urzędniku w istniejących źródłach.

16 „Bruder Kune voyt czu Natangen” - PrUB, Bd. 1/2, nr 343, 347, 350.

17 W dokumencie z 29 III 1276 r.: „frater Fridericus commendator Nathangie” - P, nr 278. W dyplomach z 1 I 1277 i 7 I 1278 r.: „frater Cuno commendator Nathangie" - UBS, nr 107; PrUB, Bd. 1/2, nr 362. 
1279 r. ${ }^{18}$, zwołana przez mistrza krajowego Prus i Inflant Konrada von Feuchtwangen do Elblaga, wspomniał, że przybyli na nią również wójtowie z Natangii i Sambii ${ }^{19}$. Tym samym więc, jeśli informacja ta jest ścisła, ponownie przywrócono by funkcję wójta natangijskiego. Jest znamienne, że kolejny po 1279 r. administrator krzyżacki dla omawianej krainy (,frater Helwicus advocatus Natangie”) w źródłach dokumentowych pojawił się 8 marca 1284 r. obok zwierzchnika nowo utworzonego komturstwa pokarmińskiego - Meinharda von Querfurt $^{20}$. A przecież wspomniany Helwig jeszcze 22 kwietnia $1283 \mathrm{r}$. pełnił urząd komtura bałgijskiego ${ }^{21}$. Ci sami krzyżaccy administratorzy (komtur pokarmiński, wójt Natangii), tym razem jednak bez zwierzchnika Bałgi, pojawili się razem w liście świadków dokumentu z 22 września $1284 \mathrm{r}^{22} \mathrm{~W}$ nieco ponad pół roku późniejszym nadaniu mistrza krajowego Konrada von Thierberg (młodszego) z 18 kwietnia 1285 r. wójt natangijski znalazł się w gronie braci z konwentu bałgijskiego ${ }^{23}$. Powyższa analiza źródeł pozwoliłaby wysunać hipotezę, że z chwilą utworzenia komturstwa pokarmińskiego urząd wójta natangijskiego mógł zostać na krótki okres podporządkowany zwierzchnikowi nowego ośrodka administracyjnego. Nie byłoby to dziwne, zważywszy że Krzyżpork, który wcześniej był siedzibą komtura, na stałe znalazł się w granicach tej nowo utworzonej jednostki administracyjnej ${ }^{24}$. Ponadto odtąd znaczna część Natangii weszła w skład komturstwa pokarmińskiego. Jednak już od 1285 r. wójt natangijski ponownie został podporządkowany komturowi bałgijskiemu i być może rezydował w podległym mu konwencie (co jednak nie jest takie pewne) ${ }^{25}$.

18 Datację tego wydarzenia ustalił U. Arnold - zob. U. Arnold, Konrad von Feuchtwangen [w:] idem, Zakon krzyżacki. Z Ziemi Świętej nad Battyk, Toruń 1996, s. 71, 94.

19 Livländische Reimchronik, wyd. L. Meyer, Paderborn 1876, s. 197.

20 PrUB, Bd. 1/2, nr 435.

21 Niedersächsische Landesbibliothek Hannover, Handfestensammlung Brandenburg (dalej: HBH), Ms XIX, 1083, k. 74; U. Nieß, Hochmeister Karl von Trier (1311-1324). Stationen einer Karriere im Deutschen Orden, Marburg 1992 („Quellen und Studien zur Geschichte des Deutschen Ordens”, Bd. 47), Anhang, nr 1, s. 204-205.

${ }^{22}$ CDW, Bd. 1, nr 68.

23 „Frater Hartungus commendator in Balga, frater Helwicus dictus de Goltbach advocatus Natangie, frater Conradus sacerdos in Balga, frater Conradus pincerna, frater Ernkonis" - PrUB, Bd. 1/2, nr 464.

24 Na ten temat zob. dalej.

25 Kolejni wójtowie natangijscy pojawiają się w dokumentach z: 11 X 1288, 2 VI 1289, 26 IV 1291 i 1292 r. - PrUB, Bd. 1/2, nr 530, 538, 575; CDW, Bd. 1, nr 91. 
Czas jednak wrócić do zasadniczego pytania, a mianowicie: kiedy dokładnie zostało wykreowane komturstwo pokarmińskie?

Punktem wyjścia dla tych poszukiwań niech będzie treść wspomnianego już dokumentu wystawionego 22 kwietnia 1283 r. w Królewcu przez krzyżackiego marszałka i wicemistrza krajowego Prus, Konrada von Tierberg (młodszego). Na jego mocy nadawał on Prusowi Kilianowi w podziękowaniu za wierną służbę jego zmarłego ojca Crisiana wieś „Laitbekes” na prawie wolnych. W liście świadków tego dokumentu wśród tytularnych administratorów-urzędników zakonnych po komturze królewieckim i wójcie sambijskim na ostatnim miejscu został wymieniony „frater Helwicus de Goltpach commendator in Balga" ${ }^{26}$, co, zważywszy na kancelaryjną praktykę stosowaną przy redagowaniu tego typu dyplomów, wskazywałoby, że to on był krzyżackim zwierzchnikiem okręgu, w którym zostało przeprowadzone nadanie. Niestety, trudno dziś wskazać, gdzie była zlokalizowana wieś „Laitbekes”, ale wymowny jest nagłówek poprzedzający w kopiariuszu odpis tego dokumentu: „Dis sint des camerampts handfestin czu Cruczberg" 27. Musiałaby więc ona się znajdować w okręgu (komornictwie) krzyżporskim (Kreuzburg), co jest o tyle istotne, iż przez cały okres istnienia komturstwa pokarmińskiego to terytorium było zlokalizowane niezmiennie w jego granicach administracyjnych ${ }^{28}$, a z konfiguracji listy świadków dokumentu z 1283 r. jednoznacznie wynikałoby, że komornictwo krzyżporskie znajdowało się wówczas $\mathrm{w}$ granicach komturstwa bałgijskiego. Jeszcze bardziej interesujace jest to, że omawiany dyplom jest chronologicznie najstarszy w zachowanym do dzisiaj kopiariuszu komturstwa pokarmińskiego, zawierającym odpisy 512 dokumentów lokacyjnych z obszaru tej jednostki administracyjnej z lat $1283-1400^{29}$. Jeżeli więc w 1283 r. dyplom

26 HBH, Ms XIX, 1083, k. 74; U. Nieß, Hochmeister Karl von Trier..., nr 1, s. 204-205.

$27 \mathrm{HBH}, \mathrm{Ms}$ XIX, 1083, k. 74.

$28 \mathrm{Na}$ co wskazuja chociażby odpisy ponad osiemdziesięciu trzynasto- i czternastowiecznych dokumentów nadań dla wsi z obszaru komornictwa krzyżporskiego (i dla samego Krzyżporka) zamieszczone w sporządzonym przed końcem 1400 r. kopiariuszu komturstwa pokarmińskiego - por. H. Härtel, Entstehung und Schicksal der wiederaufgefundenen Handfestensammlung der Komturei Brandenburg in Ostpreußen, „Preußenland” 1976, Jg. 14/1, s. 31; idem, Eine neue Quelle zur Siedlungs- und Verwaltungsgeschichte des Deutschordensstaates in Preußen, „Zeitschrift für Ostforschung” 1977, Bd. $26 / 2$, s. 307.

29 Na temat zawartości tego kopiariusza por. H. Härtel, Entstehung..., s. 28-34; idem, Eine neue Quelle..., s. 307-311. 
nadania dóbr znajdujących się w tym okręgu poświadczał wyłącznie komtur bałgijski, to nasuwa się dość oczywisty wniosek, że komturstwo pokarmińskie jeszcze wówczas nie istniało, a zostało wykreowane później.

Można wskazać także i inne dowody przemawiające za słusznościa tego toku rozumowania. Po raz pierwszy w znanych źródłach dokumentowych komtur pokarmiński (,frater Menko commendator in Brandenburg") pojawił się w liście świadków dyplomu potwierdzenia nadania wsi „Wundlaken” (dziś nieistniejącej, $10 \mathrm{~km}$ na południowy zachód od Królewca) wystawionego 8 marca 1284 r. przez pruskiego mistrza krajowego Konrada von Thierberg (młodszego) ${ }^{30}$. Nie ma wątpliwości co do tego, że miejscowość ta znajdowała się wówczas w granicach komturstwa pokarmińskiego, co wynika chociażby z faktu, iż w liście świadków tego dokumentu obok przywołanego już tamtejszego komtura zostali wymienieni inni niżsi ranga krzyżaccy urzędnicy (,frater Helwicus advocatus Natangie, frater Theodericus advocatus Sambie"), ale zabrakło w niej komtura bałgijskiego $^{31}$. W treści dokumentu szczególne zainteresowanie wzbudza jednak pewien fragment, w którym wystawca stwierdzał, że co prawda do nadania tego doszło już w czasach pruskiego mistrza krajowego Ludwika ${ }^{32}$, ale ze względu na brak ustalonych granic tej posiadłości polecił „ut dictus Bliwot [Blywot - odbiorca dokumentu, przyp. S.J., J.T.] et sui heredes sepedictum campum Wundelauches quiete possideant sub terminis, quibus frater Theodoricus [Dittrich] de Spira [Spirea] commendator in Balga circumequitando cum hominibus ibidem convicinis notabiliter designavit libere" ${ }^{33}$. Autorom niniejszego opracowania nie jest znany żaden inny taki przypadek, aby komtur sasiedniej jednostki administracyjnej przy ustalaniu granic nadawanych posiadłości, wyręczał krzyżackiego urzędnika, któremu dane terytoria podlegały ${ }^{34}$. Wyżej przeprowadzone analizy jednoznacznie natomiast wskazuja, że obszary, na których znajdowała się wieś

30 HBH, Ms. XIX, 1083, k. 111; PrUB, Bd. 1/2, nr 435.

31 Ibidem.

32 Ludwik von Beldersheim był krajowym mistrzem pruskim w latach 1264-1265 oraz 1267-1269 - por. M. Dorna, Bracia..., s. 279-280.

33 HBH, Ms. XIX, 1083, k. 111; PrUB, Bd. 1/2, nr 435.

34 Na marginesie trzeba zasygnalizować błędną interpretację treści analizowanego dokumentu dokonaną przez badaczy, według których Dietrich von Spier jeszcze 8 III 1284 r. miał być urzędującym komturem bałgijskim - zob. D. Wojtecki, Studien zur Personengeschichte..., s. 194; M. Dorna, Bracia..., s. 145; idem, Die Brüder..., s. 156 . Na ten temat zob. dalej. 
„Wundlaken”, były pierwotnie, przynajmniej od 1251 r., podporządkowane administracyjnie władzy komturów bałgijskich. W treści dokumentu z 8 marca $1284 \mathrm{r}$. byłby więc wyraźny ślad tej wcześniejszej przynależności. A dzięki zachowanym źródłom z ostatnich trzech dekad XIII w., które umożliwiają śledzenie kolejnych przekształceń administracyjnych na tym obszarze, a co za tym idzie - ustalenie chronologii ówczesnej krzyżackiej obsady urzędniczej - można się pokusić o stosunkowo dokładne określenie czasu powstania komturstwa pokarmińskiego.

Kiedy przywołany w dokumencie z 8 marca 1284 r. Dietrich von Spier mógł być zwierzchnikiem konwentu bałgijskiego? Po raz pierwszy w znanych źródłach dokumentowych pojawił się on na stanowisku komtura gniewskiego 5 marca $1283 \mathrm{r.}^{35}$, a po raz ostatni - bierzgłowskiego - 26 czerwca $1299 \mathrm{r}^{36} \mathrm{~W}$ Gniewie przebywał dowodnie do 26 lipca 1283 r. ${ }^{37}$ Nie mógł być na pewno komturem bałgijskim między 5 sierpnia 1279 a 24 kwietnia 1283 r., gdyż wówczas funkcję tę pełnił Helwig von Goldbach ${ }^{38}$. Nie był nim również 17 maja 1284 r. $^{39}$ Teoretycznie Dietrich von Spier mógłby być komturem bałgijskim między 17 stycznia 1276 a 1 stycznia $1277 \mathrm{r}^{40}{ }^{4}$, jednak w treści kluczowego dokumentu z 8 marca 1284 r. wyraźnie wspomniano, że polecenie wyznaczenia granic Dietrich von Spier otrzymał osobiście od wystawcy źródła, a mianowicie mistrza krajowego Konrada von Thierberg (młodszego), a ten obją tę funkcję po 3 września $1283 \mathrm{r}^{41}$ Tym samym należałoby przyjąć, że Dietrich von Spier był komturem bałgijskim po 26 lipca 1283, a przed 8 marca $1284 \mathrm{r}^{42} \mathrm{i}$, obsadzając wówczas ten urząd, wytyczył granice posiadłości dóbr „Wundlaken”, zanim terytorium to znalazło się w granicach nowo utworzonego komturstwa pokarmińskiego, co nastapiło najprawdopodobniej na przełomie roku 1283 i 1284.

$35 \mathrm{P}, \mathrm{nr} 352$.

36 PrUB, Bd. 1/2, nr 713.

37 P, nr 366.

38 PrUB, Bd. 1/2, nr 380 (na temat datacji tego źródła por. U. Arnold, Konrad von Feuchtwangen..., s. 73); HBH, Ms XIX, 1083, k. 74; U. Nieß, Hochmeister Karl von Trier..., Anhang, nr 1, s. 204-205.

39 „Frater Hartungus commendator in Balga” - PrUB, Bd. 1/2, nr 438.

40 W źródłach dokumentowych wzmiankowany był wówczas „frater Theodericus commendator in Bałga" - PrUB, Bd. 1/2, nr 343; UBS, nr 107.

${ }_{41} \operatorname{PrUB}$, Bd. 1/2, nr 435; UBS, nr 133. Funkcję zastępcy pruskiego mistrza krajowego Konrad von Thierberg (młodszy) sprawował zapewne już od początku 1283 r. - por. M. Dorna, Bracia..., s. 273.

42 S. Jóźwiak, Centralne i terytorialne organy..., s. 62-63. 
Ustalenie tych faktów ma ogromne znaczenie między innymi dla badań nad chronologia wznoszenia murowanego zamku w Pokarminie - siedziby nowo wykreowanego komtura i jego konwentu. Przyjmując bowiem bezkrytycznie podana przez Dusburga informację o istnieniu tamtejszego komturstwa już w 1266 r., wszyscy historycy sztuki i badacze architektury przesuwali znacznie w przeszłość moment rozpoczęcia wznoszenia tamtejszej murowanej warowni komturskiej, co - z racji tego, że była ona zbudowana na planie regularnego prostokąta (pierwotnie o trzech, później o czterech zabudowanych skrzydłach) - prowadziło ich do wniosku, że był to pierwszy (niejako wzorcowy dla późniejszych) krzyżacki zamek regularny w Prusach. Według Conrada Steinbrechta (oparł się on między innymi na badaniach wykopaliskowych, które odsłoniły kamienne filary podtrzymujące sklepienia w piwnicach, przede wszystkim w południowo-zachodnim i południowo-wschodnim skrzydle) zachowane relikty miały wyraźnie potwierdzać czas budowy zamku na lata $1260-1270^{43}$, tyle że taka datacja względna na podstawie dość przypadkowego porównywania artefaktów i detali architektonicznych w różnych obiektach zamkowych, które były skądinąd błędnie wydatowane (Bałga, Lochstedt), nie ma żadnego waloru dowodowego. Zarazem trudno watpić w to, że dla Steinbrechta punktem wyjścia do sformułowania zaprezentowanej koncepcji była po prostu informacja z kroniki Dusburga o komturze w Pokarminie pod rokiem 1266. Dość niekonsekwentny w swoich analizach na temat chronologii powstawania zamku w Pokarminie był Karl-Heinz Clasen. Z jednej strony stwierdził, że stanowi on przykład końcowego procesu przeobrażania krzyżackiej warowni w murowany, zamknięty, regularny „kasztel” („Kastell”), z drugiej natomiast czas jego budowy datował na lata 1280-1290 (północno-zachodnie skrzydło jeszcze później - na XIV w. ${ }^{44}$. Badacz ten wspomniał także, że w sumie zachowało się bardzo niewiele źródeł, które pozwalałyby śledzić proces wznoszenia tego zamku ${ }^{45}$. Nic nowego w poruszanej tu kwestii nie miał do powiedzenia Emil Johannes Guttzeit. Powołując się na prace

43 C. Steinbrecht, Preussen zur Zeit der Landmeister. Beitraege zur Baukunst des Deutschen Ritterordens, Berlin 1888 (Die Baukunst des Deutschen Ritterordens in Preussen, Bd. 2), s. 106.

44 K.-H. Clasen, Die mittelalterliche Kunst im Gebiet des Deutschordensstaates Preussen, Bd. 1: Die Burgbauten, Königsberg 1927, s. 31, 47-48.

45 Ibidem, s. 31. Gdy bierze się pod uwagę wyłącznie źródła architektoniczne, to trudno nie zgodzić się z tym badaczem. Tyle że istnieją również średniowieczne przekazy pisane, których Clasen w ogóle nie brał pod uwagę. Na ten temat zob. dalej. 
Steinbrechta i Clasena przyją, że murowany zamek w Pokarminie zbudowano między 1270 a 1280 r. ${ }^{46}$, a konwent krzyżacki z komturem miał zostać ulokowany w tamtejszej warowni drewniano-ziemnej w $1266 r{ }^{47}$ Najnowszym głosem w dyskusji na ten temat sa propozycje Tomasza Torbusa i Kazimierza Pospiesznego. Pierwszy z nich uznał, że zamek wysoki w Pokarminie (określał go mianem „domu konwentu") wzniesiono na planie regularnym (czworobocznym), ale pierwotnie był on założeniem trójskrzydłowym (czwarte zostało dobudowane w XIV w.). Gdy chodzi o samą chronologię wznoszenia murowanej warowni, Torbus próbował pogodzić ze sobą propozycje wcześniejszych uczonych i doszedł do wniosku, że jej budowa trwała od 1270 do 1290 r. ${ }^{48} \mathrm{Z}$ kolei Kazimierz Pospieszny, zupełnie bezkrytycznie powielając pomysły Voigta i Steinbrechta, stwierdził, że zamek w Pokarminie był jedna z trzech najstarszych regularnych murowanych warowni krzyżackich nad Zalewem Wiślanym ${ }^{49}$.

Tymczasem gruntowna analiza nieuwzględnianych dotąd przez badaczy źródeł pisanych pozwala dokonać kilku nowych interesujacych ustaleń w kwestii chronologii wznoszenia murowanego zamku komturskiego w Pokarminie, przynajmniej w jego poczattkowej fazie. Przede wszystkim jest rzeczą bardzo wątpliwa, by jego budowa ruszyła przed podjęciem przez władze krzyżackie decyzji o utworzeniu konwentu komturskiego w Pokarminie, co - jak starano się wykazać wyżej - miało miejsce pod koniec 1283 lub też na samym początku $1284 \mathrm{r}$. Informacje zawarte w istniejących źródłach pisanych wyraźnie zresztą wskazuja na to, że począwszy od połowy XIII w. to bynajmniej nie Pokarmin był brany pod uwagę jako główny ośrodek administracyjny dla Natangii. W zredagowanym najpóźniej w drugiej połowie XIV w. ${ }^{50}$ Canonici

46 E.J. Guttzeit, Die Ordensburg Brandenburg..., s. 111, 116. Autor zawarł tutaj nieścisłą informację, gdyż - jak wspomniano wyżej - Clasen przyją nieco późniejsza chronologie rozpoczęcia prac nad zamkiem murowanym w Pokarminie.

47 Ibidem, s. 118.

48 T. Torbus, Zamki konwentualne państwa krzyżackiego $w$ Prusach, Gdańsk 2014, s. 101-105; idem, Die Konventsburgen im Deutschordensland Preussen, München 1998 (,Schriften des Bundesinstituts für ostdeutsche Kultur und Geschichte”, Bd. 11), s. 97-99 (choć w innym miejscu tego opracowania Torbus opowiedział się za budową zamku wysokiego w Pokarminie w latach 1267-1290 - ibidem, s. 372).

49 K. Pospieszny, „Domus Malbork”. Zamek krzyżacki w typie regularnym, Toruń 2014, s. 252.

50 Najbardziej prawdopodobny czas zredagowania tego źródła to lata 1338-1352, ale nie ma co do tego pewności - zob. S. Zonenberg, Kto byt autorem Epitome Gestorum Prussie?, ZH 2013, t. 78, s. 85-102. 
Sambiensis epitome gestorum Prussie dwukrotnie powtórzono informację o wzniesieniu już w 1253 r. krzyżackiej warowni w Krzyżporku ${ }^{51}$. Odegrała ona ważną rolę $\mathrm{w}$ trakcie powstania pruskiego w początkach lat sześćdziesiątych XIII w ${ }^{52}$ Jak już o tym wspominano, po stłumieniu kolejnego wielkiego powstania pruskiego warownia ta na jakiś czas (przynajmniej w połowie lat siedemdziesiątych XIII w.) stała się nawet siedzibą konwentu komturskiego. A jednak istnieje jednoznaczny dowód na to, że co najmniej do 1315 r. nie miała ona charakteru zamku murowanego. Oto bowiem w wystawionym 21 stycznia 1315 r. przez wielkiego komtura Henryka von Plötzkau dokumencie lokacyjnym miasta Krzyżporka zostały sprecyzowane między innymi zasady korzystania przez jego mieszkańców z nieodległego lasu „Hegewalt”. Wystawca zagwarantował stronie krzyżackiej możliwość swobodnego pozyskiwania drzew na potrzeby zabudowań tamtejszej warowni, ale nie jej zewnętrznych obronnych obwarowań $\mathrm{z}$ bali ${ }^{53}$, a te informacje pozwalałyby sądzić, że obiekt ten nadal nie był jeszcze w tym czasie ceglanym zamkiem murowanym. Tak musiało być także w II połowie XIII w. W takiej więc warowni w połowie lat siedemdziesiątych tego stulecia rezydowałby tamtejszy konwent z komturem na czele. Jeszcze bardziej enigmatyczne sa informacje dotyczace siedziby przywołanego wyżej wójta, a w latach 1276-1278 - komtura natangijskiego. Z końca XIII i pierwszej połowy XIV w. nie ma żadnych informacji źródłowych, które pozwoliłyby stwierdzić, czy urzędnik ten rezydował w Krzyżporku, Bałdze czy też na krótko (od 1284 r.) w Pokarminie. Uwagę przyciaga tu treść dokumentów z 18 sierpnia 1341, 4 lutego 1364 i 25 lutego 1392 r., które przez wielkich mistrzów i komturów bałgijskich zostały wystawione „in curia nostra Nattangynen” (,in unserm hofe Natangen”) ${ }^{54}$. Ten nieistniejący współcześnie „dwór” był najprawdopodobniej zlokalizowany w miejscowości Ruschenhof (Reuschenhof) nad Zalewem Wiślanym, $4 \mathrm{~km}$ na północ od Heiligenbeil (dziś Mamonowo, Rosja), w granicach ówczesnego komturstwa bałgijskiego. Czy w końcu XIII w. mogłaby się tam mieścić siedziba krzyżackiego wójta Natangii? Tego nie wiadomo, ale z samej charakterystyki obiektu

51 Canonici Sambiensis epitome gestorum Prussie, hrsg. v. M. Töppen [w:] SRP, vol. 1 , s. $280,282$.

52 Dusburg, s. 118-119, 129.

53 „[...] in qua nobis pro utilitate castri nostri Cruceburg tamen ligna ad edificia et non ad plancas tempore indigencie reservamus" - PrUB, Bd. 2, nr 124.

54 PrUB, Bd. 3/1, nr 396, 397, 398, 399; Bd. 6/1, nr 243; HBH, Ms XIX, 1083, k. $112 \mathrm{v}-113$. 
zawartej w przywołanych tu źródłach wynika, że nie był to na pewno zamek murowany.

Pozostaje więc w tym miejscu wrócić do zasadniczej kwestii i spróbować poszukać odpowiedzi na pytanie, na jaki okres przypadła pierwsza faza budowy kamienno-ceglanego zamku komturskiego w Pokarminie. Uwage przyciaga wystawiony tam („datum Brandenburch”) 14 lutego 1290 r. przez pruskiego mistrza krajowego Meinharda von Querfurt dokument nadania dla Prusów Busso i Hertwiga 60 łanów ziemi we wsi Pokarben (dziś nieistniejąca, $2 \mathrm{~km}$ na południowy wschód od Pokarmina). Co prawda fakt wymienienia w liście świadków tego dokumentu komtura pokarmińskiego Ludwika von Schüpf nie wnosi nic konkretnego do prowadzonych tu rozważań, jednak znacznie bardziej wymowny jest zapis przywołujący ostatniego świadka: „frater Albertus vicecommendator domus Brandenburg"55. Jakkolwiek tłumaczyć użycie tu łacińskiego rzeczownika „domus” ${ }^{56}$, trudno kwestionować, że kryłby się pod nim murowany dom konwentu, czyli komturski zamek w Pokarminie, oczywiście nie w formie gotowej, trój- lub czteroskrzydłowej, ale przynajmniej z jednym, głównym, południowo-zachodnim skrzydłem z kaplicą i refektarzem, w ramach zamkniętego murem kurtynowym prostokatnego założenia. Nie mniej ciekawa w tym kontekście jest wzmianka zawarta w zeznaniu procesowym złożonym przez Henryka, przeora klasztoru cysterskiego w Falkenau w diecezji dorpackiej (obecnie Kärkna, 8 km na północ od Tartu, Estonia), w prowadzonym w 1312 r., z polecenia papieża Klemensa V, przez kanonika i inkwizytora Franciszka de Moliano i arcybiskupa Jana z Bremy postępowaniu procesowym przeciwko inflanckiej gałęzi zakonu krzyżackiego w jej konflikcie $\mathrm{z}$ arcybiskupem ryskim Fryderykiem von Pernstein. Zeznający zaprezentował wiedzę między innymi na temat wprowadzonych przez Krzyżaków restrykcji w kontaktach tamtejszego duchowieństwa z kurią papieska w Rzymie/Awinionie. Sam bowiem padł ich ofiara, kiedy taką właśnie podróż odbywał. Działo się to sześć lat wcześniej (a więc w 1306 r.), w poniedziałek 21 marca ,iuxta castrum nomine Brandenberg situm in Pruscia”, gdzie zeznający przeor Henryk został zatrzymany i był maltretowany przez tamtejszego brata-rycerza krzyżackiego Jana

$55 \quad$ PrUB, Bd. 1/2, nr 557.

56 „Domus” - budynek, budowla, dom, budynek mieszkalny, mieszkanie, siedziba, dom zakonny, klasztor, konwent - zob. Stownik łaciny średniowiecznej w Polsce, t. 3, red. M. Plezia et al., Wrocław 1972, s. 844-849. 
„de Niphel” i niewymienionych z imienia ludzi komtura królewieckiego i krajowego mistrza Inflant ${ }^{57}$. Niewatpliwie była tu mowa o zamku w Pokarminie. Otwarte pozostaje jednak pytanie, na jakim etapie wznoszenia wówczas (a więc w 1306 r.) się znajdował. Skoro utrwalił się w pamięci przeora Henryka, stanowił już zapewne istotny i charakterystyczny punkt terenu. W warowni tej poszkodowany mógł być również przetrzymywany, choć nie wynika to bezpośrednio z samego zeznania.

Podsumowując przeprowadzoną analizę, należy stwierdzić, że murowany zamek komturski w Pokarminie zaczęto wznosić w latach osiemdziesiątych XIII w. (być może około 1283 r.), co zbiegło się z decyzją ulokowania tam siedziby konwentu i komtura krzyżackiego. Stało się to pod koniec 1283 lub na początku $1284 \mathrm{r}$. W jakiejś formie (główne skrzydło wraz z obiegajacym całe założenie murem kurtynowym?) zamek był już gotowy w 1290 r. Na początku XIV w. (przed 1306 r.) uzyskał formę dwu- lub trójskrzydłową na planie prostokata. W żadnym razie warownia w Pokarminie nie była pierwszym lub też wzorcowym zamkiem regularnym w państwie zakonnym w Prusach, co do tej pory przyjmowali niemal wszyscy uczeni. Poszukiwania odnośnie do tej kwestii ciagle sa prowadzone, ale badacze coraz częściej wskazują na Papowo w ziemi chełmińskiej jako pierwszy, regularny (kwadratowy), czteroskrzydłowy zamek komturski w Prusach ${ }^{58}$. Nie ma jednak pewności, czy do końca XIII w. był on już w całości wzniesiony.

57 „Interrogatus, in quo loco fuerit tunc, quando predicta substinuit, respondit, quod iuxta quoddam castrum nomine Brandenberg situm in Pruscia. Interrogatus de tempore respondit, quod essent sex anni, et fuit feria secunda post dominicam Iudica. Interrogatus, qui fuerint illi fratres, qui sibi illa intulerunt, respondit, quod unus fuit frater Iohannes de Niphel ordinis fratrum predictorum et alii fuerint servi fratrum, quorum unus sagittarius ex eis erat servus commendatoris in Cunningsbergh, et alii magistri generalis de Lyvonia" - Das Zeugenverhör des Franciscus de Moliano (1312). Quellen zur Geschichte des Deutschen Ordens, hrsg. v. A. Seraphim, Königsberg i. Pr. 1912, s. 41; PrUB, Bd. 2, nr 86, s. 55.

58 Na ten temat zob. ostatnio B. Wasik, Budownictwo zamkowe w ziemi chetmińskiej (od XIII do XV wieku), Toruń 2016, s. 271-276. 


\begin{abstract}
The time of the establishment of the commandery in Pokarmin

(Brandenburg) and the issue of the chronology of the erection of the local castle
\end{abstract}

The analyses performed in the paper indicate that the construction works on the brick Teutonic Commandery Castle in Pokarmin (Brandenburg) started in the 1280s (perhaps around 1283). This coincided with the decision to make it the headquarters of the order and the seat of the commander, which took place at the end of 1283 or at the beginning of 1294. The castle was more or less finished (the main wing and the curtain wall surrounding the whole site?) in 1290. At the beginning of the $14^{\text {th }}$ century (before 1306) it had two or three wings and was built on a rectangular plane. By no means was the castle in Pokarmin the first or model regular castle in the State of the Teutonic Order in Prussia, which was a common assumption among scholars up until now. This issue is still being researched, but more and more information points to Papowo in the Chełmno land as the first regular (square), four-wing commandery castle in Prussia. We are still not certain, however, if by the end of the $13^{\text {th }}$ century its construction had been completed. 